\title{
Pyroclastic flow deposits from a kimberlite eruption: Orapa South Crater, Republic of Botswana
}

\author{
T. M. Gernon ${ }^{1}$, M. Field ${ }^{1}$, R. S. J. Sparks ${ }^{1}$, R. J. Brown ${ }^{1}$, G. Fontana ${ }^{2}$ and C. Mac Niocaill ${ }^{2}$ \\ ${ }^{I}$ Department of Earth Sciences, University of Bristol, Bristol, BS8 1RJ, UK \\ ${ }^{2}$ Department of Earth Sciences, University of Oxford, Parks Road, Oxford OXI 3PR, UK
}

\begin{abstract}
Orapa Diamond Mine, Republic of Botswana, exposes a bi-lobate kimberlite pipe $(\mathrm{A} / \mathrm{K} 1)$, erupted during the Late-Cretaceous period ( $\sim 93 \mathrm{Ma})$ through Archaean basement and volcano-sedimentary rocks of the Phanerozoic Karoo Supergroup. Geological mapping of the crater zone of the South Pipe has revealed a 15$20 \mathrm{~m}$ thick in-situ kimberlite pyroclastic flow deposit. The unit comprises a basal coarse lithic concentration layer exhibiting imbricated clasts, which grades upwards into massive poorly sorted lapilli tuff, permeated by sub-vertical gas-escape structures defined by lithic enrichment and fines depletion. Degassing structures commonly emanate from outsize lithic clasts in the basal layer. The presence of degassing structures and a coarse basal layer distinguishes this deposit from typical pipe-filling volcaniclastic kimberlite, which is homogeneous in terms of texture and clast size over distances in the order of 100 s metres. Studies of the Thermal Remnant Magnetism (TRM) in basalt clasts from the deposit indicate that the deposit was emplaced at elevated temperatures; preliminary results suggest $300-380^{\circ} \mathrm{C}$, consistent with deposition from a pyroclastic density current. The pyroclastic deposit infills the crater and completely drapes lower units, indicating that the parent flow originated from an adjacent kimberlite pipe. The facies characteristics can be explained by the interaction of the pyroclastic flow with the complex topography of a pre-existing crater.
\end{abstract}

\section{Introduction}

Due to the extensive erosion that occurs in cratonic regions, kimberlite craters are not commonly preserved. Examples of craters include the Orapa A/K1 Pipes, Botswana (Field et al., 1997) and the Mwadui Pipe, Tanzania (Stiefenhofer and Farrow, 2004), both of which contain re-sedimented volcaniclastic kimberlite (VK) and crudely-layered pyroclastic units. The latter are envisaged by Field et al. (1997) and Stiefenhofer and Farrow (2004) to have formed in-situ by sustained deposition from high-concentration eruption columns. Sparks et al. (2006) present an emplacement model in which primary pyroclastic processes (i.e. pyroclastic fall, flow and surges), which deposit both layered and massive VK, are important in the later stages of kimberlite eruptions.

Leahy (1997) and Leckie et al. (1997) describe tephra fall tuff deposits from flat-lying crater deposits of the Forte à la Corne kimberlite field, Saskatchewan, Canada. Pyroclastic flow deposits have been reported from the Orapa A/K1 kimberlite, Botswana, and are interpreted to have derived from a neighbouring pipe in the Orapa cluster (Gernon, 2007; Gernon et al., 2008; Gernon et al., in press). A similar style of crosscontamination between kimberlite pipes has been invoked for the Diavik Pipe (Moss et al., in press) and Ekati Fox Pipe (Porritt et al., in press), NWT Canada.

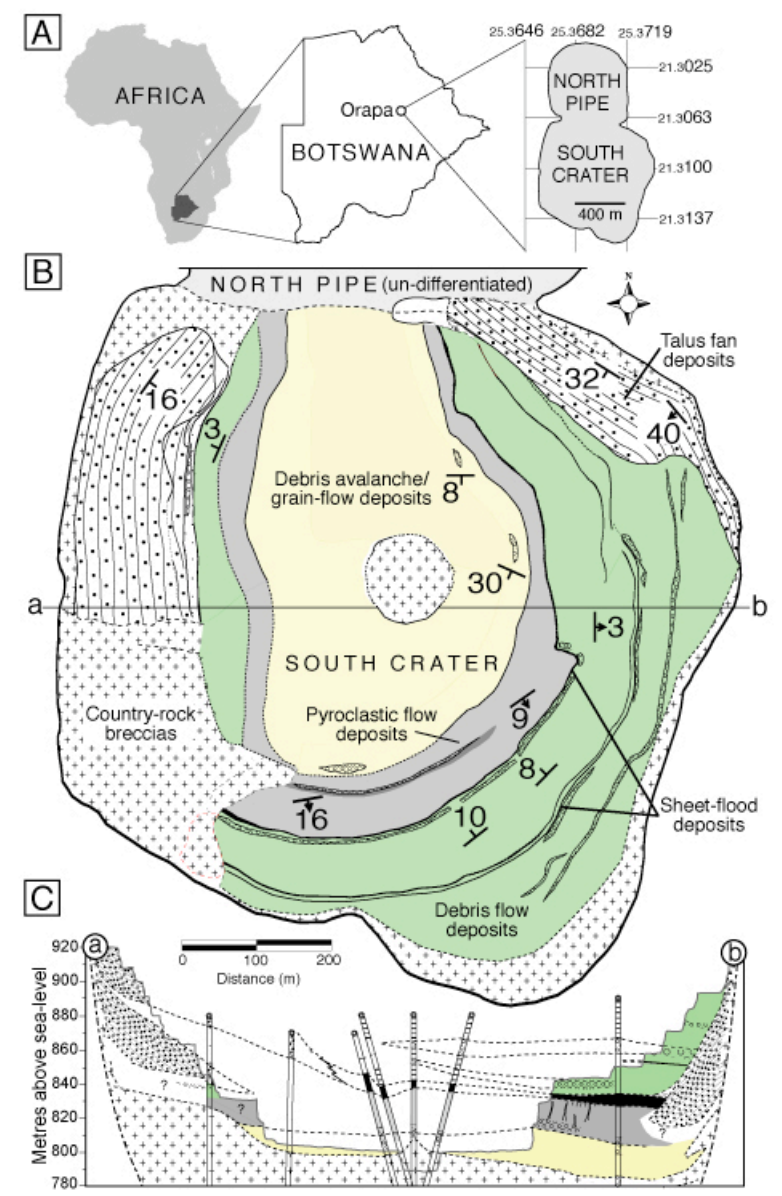

Figure 2: (A) Map of Botswana showing the regional context of the Orapa A/K1 body; (B) Summary geological map of the Orapa South Crater; (C) Schematic cross-section $a-b$ (see B)

In this paper, we describe, from bench exposures in the Orapa South Crater, the kimberlite 
unit that we interpret as a pyroclastic flow deposit. Detailed descriptions of the constituent lithofacies are provided and discussed in terms of grain-size characteristics, structure and fabrics defined by clast major-axis orientations. Based on stratigraphic relationships, we show that kimberlite pyroclastic units can deposit in older craters and consequently are not necessarily related to the pipe in which they are found.

\section{Field observations}

The Orapa South Pipe (Fig. 1) consists of a stratiform crater-fill sequence (Gernon et al., in press). Benches in the upper part of the pipe expose a $15 \mathrm{~m}$ high and 250 $\mathrm{m}$ long section through the pyroclastic unit (Fig. 2), which is divided into a basal matrix-supported breccia facies and upper massive facies of lapilli tuff.

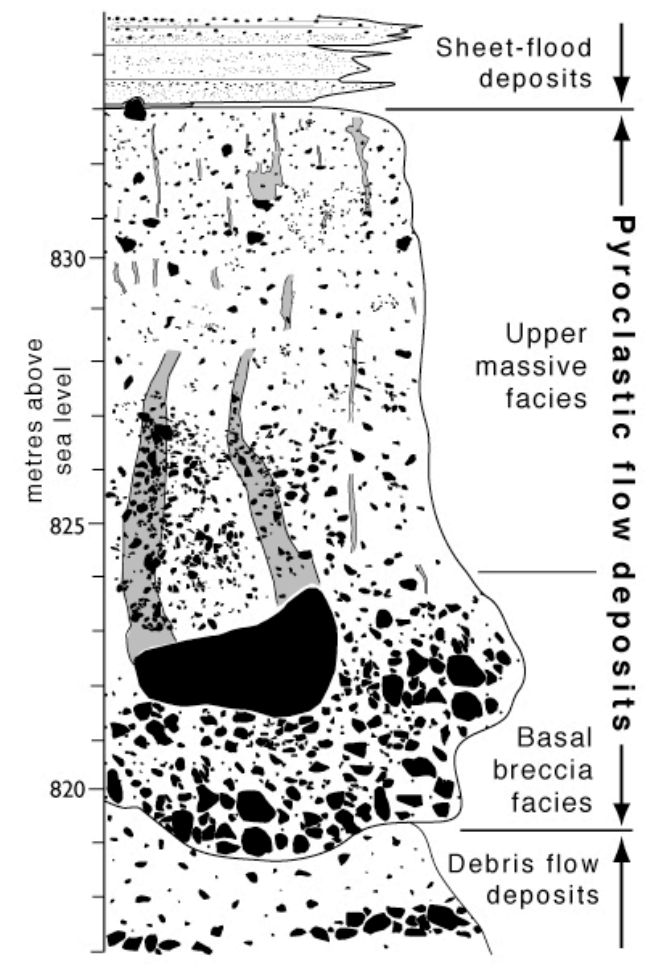

Figure 2: Schematic log showing a typical section through the pyroclastic flow deposit (modified from Gernon et al. (in press)). Grey regions represent degassing structures.

\section{Massive facies}

The massive facies (Fig. 2) consists of poorly-sorted lithic clasts $(\sim 10 \%$ area $)$ and vesicular grains in a matrix of altered olivine crystal fragments (size range: $250 \mu \mathrm{m}-2 \mathrm{~mm}$ ) and trace amounts of garnet, chrome diopside and ilmenite. The interstices between primary grains are occupied by low birefringence serpentine and minor calcite with void-filling (grainstone) textures. Basaltic clasts dominate the lithic population, though several mantle nodules, basement schists and gneisses were also identified. The overall texture is massive, with no layering. Fabric studies along the benches show lithic clast orientations to vary from place to place. In most places there is a moderate to strong tendency for long-axes in the plane of the bench exposure to plunge towards the south-west. In areas with abundant pipes the long-axes become steeper and the imbricate (south-west) fabric is lost.

\section{Degassing structures}

The massive facies hosts abundant well-developed subvertical structures enriched in lithic fragments (size range $=1 \mathrm{~mm}-53.5 \mathrm{~cm}$ ) and large crystals (size range $=750 \mu \mathrm{m}-6.6 \mathrm{~mm}$ ), and almost devoid of the finemedium crystals and minor lithic components that comprise the surrounding matrix (Gernon et al., 2008). In these structures, the matrix proportion $(5-10 \%)$ is lower than that in the host massive facies (55-60\%), and the structures are therefore marginally better sorted. The pipes are internally structureless and clast supported, containing angular to sub-rounded lithic clasts and crystals.

The inter-clast space of the degassing structures is characteristically infilled by secondary calcite and a yellowish serpentine in void-filling textures. Polished slabs and thin sections show that void-filling serpentine is associated with concentrations of large olivines. Components for the serpentine infill $(\mathrm{Mg}, \mathrm{Si}, \mathrm{H})$ are released from the olivine structure to locally infill the voids between olivine crystals during serpentinisation (Stripp et al., 2006).

\section{Basal breccia facies}

A laterally discontinuous $\sim 5 \mathrm{~m}$ thick coarse matrixsupported breccia (Fig. 2; 70\% matrix; 30\% lithic clasts) forms the base of the unit. It is monolithic and texturally immature, containing angular to sub-angular basaltic clasts. The composition and texture of the matrix is identical to that of the massive facies. As observed in the massive facies, studies of clast size distributions demonstrate a range in sizes from $2.4 \mathrm{~cm}$ to $3.6 \mathrm{~m}$. It is very poorly sorted. Lithic clasts exhibit a strong fabric orientation with the majority of long-axes plunging towards the south-west in the plane of the section. The basal part of the facies contains occasional basalt boulders with maximum dimensions of order 2 to $4 \mathrm{~m}$. The sub-vertical lithic rich pipes described emanate from the sides and tops of these boulders.

\section{Discussion}

We have documented a basal imbricated breccia (comprising $\sim 30 \%$ area lithics) which grades upwards into a massive facies (comprising $\sim 10 \%$ area lithics) that hosts abundant fines-poor vertical structures, which we attribute to fluid escape. These are all characteristic features of pyroclastic flow deposits (Walker, 1971; Sparks, 1976; Cas and Wright, 1987; Branney and Kokelaar, 2002). Preliminary results of TRM of basalt clasts from the deposit indicate that it was emplaced at $300-380^{\circ} \mathrm{C}$, consistent with deposition from a pyroclastic density current. The pyroclastic deposit forms part of a stratified volcaniclastic sequence across the entire pipe (Fig. 1). It drapes a clast-supported lithic breccia unit (Gernon et al., in press), which itself completely drapes lower vent-fill and therefore cannot be derived from the host pipe. 
Since the South Crater post-dates emplacement of the North Pipe (Field et al., 1997), we infer that the pyroclastc flow originated from an adjacent pipe complex. Within a $20 \mathrm{~km}$ radius of $\mathrm{A} / \mathrm{K} 1$, approximately 25 kimberlite bodies have been discovered, mainly to the south and east.

\section{Deposition of the basal facies}

The basal lithic concentration horizon is interpreted to represent a lithic lag breccia deposited rapidly upon deceleration of a pyroclastic flow. They can form in a variety of environments from proximal to distal. At Orapa, the lag breccias are attributed to the interaction of the pyroclastic flow with the local topography as it entered the Orapa South Crater, entraining locally derived basalt clasts that would have characterised loose slope talus and walls of the pre-existing crater. This environment favours the formation of local lag breccias, with outsize clasts and degassing structures.

\section{Evidence for fluidisation}

The degassing structures are hosted by a massive lapilli tuff, and are compared to elutriation pipes described from ignimbrites (Walker, 1971; Sparks et al., 1985; Branney and Kokelaar, 2002). The structures are unsheared and therefore formed after rapid deposition of the pyroclastic flow. Observations show that the degassing structures originally contained little matrix, with the original voids infilled by up to $25 \%$ secondary calcite and serpentine. This can be explained by the gas-driven elutriation of fine particles from the pipes (Walker, 1971). Gas may have been sourced from volatile exsolution, attrition between particles, boiling of groundwater or most probably entrainment of air as the pyroclastic flow entered the South Crater.

\section{Conclusions}

We have documented kimberlite pyroclastic flow deposits with associated degassing structures. The pyroclastic flow deposit formed a continuous sheet across the Orapa South Pipe, indicating that the flow originated from another kimberlite vent and was emplaced into the Orapa South Crater. This type of cross-contamination within kimberlite clusters has major implications for diamond exploration and the economic evaluation of pipes. Recognition of this specific kimberlite deposit requires an eruption process capable of: (1) comprehensive fragmentation, (2) production of gas-charged mass flows, and (3) significant transport away from the vent. The facies of the pyroclastic flow deposit are typical of an environment where the flow encounters complex topography.

\section{References}

Branney, M.J., Kokelaar, P., 2002. Pyroclastic density currents and the sedimentation of ignimbrites. Geological Society, London, Special Publication, 27.

Cas, R.A.F., Wright, J.V., 1987. Volcanic Successions: Modern and Ancient. Allen and Unwin.
Field, M., Gibson, J.G., Wilkes, T.A., Gababotse, J., Khutjwe, P., 1997. The geology of the Orapa A/K1 kimberlite Botswana: further insights into the emplacement of kimberlite pipes. Russian Geology and Geophysics, 38 (1), 24-39.

Gernon, T.M. 2007. Fluidisation and emplacement processes in kimberlite eruptions. Ph.D. thesis, University of Bristol.

Gernon, T.M., Field, M., Sparks, R.S.J. 2008. Degassing structures in volcaniclastic kimberlite: Examples from southern African kimberlite pipes. Journal of Volcanology and Geothermal Research, doi: 10.1016/ j.jvolgeores.2007. 12.035 .

Gernon, T.M., Field, M., Sparks, R.S.J. In press. Depositional processes in a kimberlite crater: the Upper Cretaceous Orapa South Pipe (Botswana). Sedimentology.

Leahy, K., 1997. Discrimination of reworked pyroclastics from primary tephra-fall tuffs: a case study using kimberlites of Forte à la Corne, Saskatchewan, Canada. Bulletin of Volcanology, 59, 65-71.

Leckie, D.A., Kjarsgaard, B.A., Bloch, J., McIntyre, D., McNeil, D., Stasiuk, L., Heaman, L., 1997. Emplacement and reworking of Cretaceous, diamond-bearing, crater facies kimberlite of central Saskatchewan, Canada. Geological Society of America Bulletin, 109 (8), 1000-1020.

Moss, S., Russell, J.K., Andrews, G.D.M. In press. Progressive infilling of a kimberlite pipe at Diavik, Northwest Territories, Canada: Insights from volcanic facies architecture, textures, and granulometry. Journal of Volcanology and Geothermal Research.

Mitchell, R.H., 1986. Kimberlites: Mineralogy, Geochemistry, and Petrology. Plenum Press.

Mitchell, R.H., 1995. Kimberlites, orangeites, and related rocks. Plenum Press.

Porritt, L.A., Cas, R.A.F., Crawford, B.B. In press. In-vent column collapse as an alternative model for massive volcaniclastic kimberlite emplacement: An example from the Fox kimberlite, Ekati Diamond Mine, NWT, Canada. Journal of Volcanology and Geothermal Research.

Sparks, R.S.J., 1976. Grain-size variations in ignimbrites and implications for the transport of pyroclastic flows. Sedimentology, 23, 147-188.

Sparks, R.S.J., Francis, P.W., Hamer, R.D., Pankhurst, R.J., O'Callaghan, L.O., Thorpe, R.S., Page, R., 1985. Ignimbrites of the Cerro Galan Caldera, NW Argentina. Journal of Volcanology and Geothermal Research, 24, 205-248.

Sparks, R.S.J., Baker, L., Brown, R.J., Field, M., Schumacher, J., Stripp, G., Walters, A., 2006. Dynamical constraints on kimberlite volcanism. Journal of Volcanology and Geothermal Research, 155, 18-48.

Stiefenhofer, J., Farrow, D.J., 2004. Geology of the Mwadui kimberlite, Shinyanga district, Tanzania. Lithos, 76, 139-160.

Stripp, G.R., Field, M., Schumacher, J.C., Sparks, R.S.J., Cressey, G., 2006. Post emplacement serpentinization and related hydrothermal metamorphism in a kimberlite from Venetia, South Africa. Journal of Metamorphic Geology, 24, 515-534.

Walker, G.P.L., 1971. Grain-size characteristics of pyroclastic deposits. Journal of Geology, 79, 696-714. 